\title{
Analysing Interdependencies of Complex Engineering Systems using a Digital Twin-Driven Design Structure Matrix
}

\author{
Long CHEN $^{1,2}$ and Jennifer WHYTE ${ }^{1,2}$
}

${ }^{1}$ Centre for Systems Engineering and Innovation, Department of Civil and Environmental Engineering, Imperial College London

2 Lloyds Register Foundation/Alan Turing Institute Data Centric Engineering Programme, The Alan Turing Institute

Email: long.chen@imperial.ac.uk; j.whyte@imperial.ac.uk

\begin{abstract}
As engineering design process becomes increasingly complex and interconnected, multidisciplinary teams need to work together, integrating diverse expertise across disciplinary models. Design team often finds it difficult to handle the complexity and interdependencies in both engineering systems and collaborative design process. Previous efforts have been made to address this problem through tracking the system interdependencies using Design Structure Matrix (DSM). However, it is still challenging to deal with complex systems with large data sets and multiple disciplines involved. This paper proposes an effective way to simplify complexity and clarify interdependencies in complex systems through generating DSM from a digital twin (e.g., building information modelling). It firstly defined Elements in the digitally generated DSM (Digital-DSM) drawing on the Uniclass 2015 classification system and prior work, of which three levels were classified as systemof-systems level, project level, and asset level. Interdependencies in Digital-DSM were then defined for different levels of Elements correspondingly based on the geometric and semantic information in Industry Foundation Classes (IFC). Finally, a prototype has been constructed to illustrate how the Digital-DSM helps to improve the efficiency of late design change in complex engineering systems. The results show that the proposed Digital-DSM can initiate a leaner design process through analysing interdependencies and further tracking the propagation of design changes clearly and conveniently.
\end{abstract}

\section{INTRODUCTION}

Through a series of infrastructure projects and programmes including those at Heathrow, London 2012 Olympics, Crossrail, Tideway and High-Speed 2 (HS2), the UK is developing significant expertise in the delivery of major infrastructure projects. (Whyte, 2019; Davies, 2017). To address the challenges of infrastructure delivery, multidisciplinary teams need work together, integrating diverse expertise across disciplines. One challenge that arises is that design teams find it difficult to understand the impacts of late design changes in such complex systems (e.g., infrastructure projects), where changes in one sub-system may have implications for others (Whyte et al., 2016). The interdependencies in such complex engineering systems should be clarified to help designers improve work efficiency in design changes.

While data consistency and quality has traditionally been relatively poor, such complex engineering systems and projects are becoming rich sources of data from 
multidisciplinary models and systems (Whyte et al., 2016), raising new opportunities to model and understand the interdependencies in the design of new and operation of existing infrastructure projects.

There have been many efforts in identifying system interdependencies from complex infrastructure projects. For instance, Eusgeld et al. (2011) proposed an 'system-of-systems' approach to identify and analyse interdependencies between industrial control systems (ICS). Goldbeck et al. (2019) stepped forward in developing a new, effect-based classification of interdependencies between infrastructure systems. With the increasing complexity of infrastructure projects, design structure matrix (DSM) has been further introduced as a simple, compact and visual representation of a complex system to model system decomposition and interdependencies (Browning, 2001). The DSM has been adopted widely to model and analyse the product decomposition and interdependencies (Pimmler and Eppinger, 1994), to show data interdependencies in multidisciplinary design process (Lambe and Martins2012), and to formulate the interdependencies between drawings of physical components at the lowest level of abstraction in construction design (Senthilkumar and Varghese, 2009). However, current methods for identifying and managing these interdependencies are inadequate for increasingly integrated and cyber-physical complex systems, and do not make full use of such rich sources of data and translate well into a digitally enabled built environment.

The developments of information and communication technologies (ICT), especially building information modelling (BIM) techniques, provide the way to transfer complex systems into the digitally enabled built environment. The Industry Foundation Classes (IFC) as a standard representation of BIM knowledge for interoperability has further opened the possibility to integrate DSM with digital data for more convenient identification of system interdependencies and for more effective design management. Inspired by the interoperability of BIM, Pektas (2010) proposed the complementary integration of IFC process modelling (e.g., IDEF0) and parameterbased DSM in modelling collaborative building design process. Jacob and Varghese (2011) proposed a logic of integration of BIM and DSM to improve construction design process through the definition of new classes 'IfcDSM' and 'IfcConnenctsByInformation'. Based on that, Jacob and Varghese (2012) further made efforts to address design process complexity derived from the increased sophistication of product models through integrating the process model (e.g., IFC process model and DSM) with the product model (i.e., IFC product model). However, these efforts were mainly established on the hypothesis of potential IFC extensions (e.g., IfcDSM), and were limited to activity/process-based DSM to identify manually identified system interdependencies and improve construction design process. Gopsill et al. (2016) succeeded in automatically generating component-based DSM to deal with component interdependencies by monitoring the changes in the digital models representing the product. Saoud et al. (2017) proposed the integration of parameter-based DSM with BIM to identify interdependencies between design parameter relationships, supporting and managing the visual representation of predicting design change propagation. Although these efforts have succeeded in identifying system interdependencies between components or design parameters, the work of Gopsill et al. (2016) is inadequate for clarifying and classifying different kinds of interdependencies between 
components, and the work of Saoud et al. (2017) is still heavily dependent on manually identified interdependencies between design parameters. There is a need to identify and clarify system interdependencies automatically for complex systems through integrating the digital model (e.g., BIM) and DSM.

This paper aims to develop a novel and effective way to simplify complexity and clarify interdependencies in complex systems through generating DSM from a digital twin (e.g., BIM). It firstly reviewed the past research in identifying system interdependencies using DSM, and briefly introduced the theoretical foundation of this work, including digital twin, IFC and Uniclass classification system. Based on that, the Digital-DSM was defined to clarify the elements and their associated interdependencies across levels (i.e., asset level, project level, and system-of-systems level). Finally, the strategy has been provided to generate Digital-DSM from digital twin at the asset level for example. A simple demonstrating case study has been also conducted to illustrate how the asset level Digital-DSM can be generated and helps to improve the efficiency of late design change via identifying and analysing system interdependencies. This research and results can provide a first step toward next-generation complex engineering systems by demonstrating the feasibility of using a digital twin to generate new insight on systems relationships and interdependencies. The use of digital data and analytics can enable engineering decision-makers to rapidly understand interdependencies within projects and across their boundaries in complex engineering systems with growing complexity.

\section{BACKGROUND}

\section{System interdependencies and design structure matrix}

The infrastructure projects in the UK is subject to ever increasing loads for population growth, where the addition and retrofit of new/existing infrastructure that is constrained by, and should function harmoniously with, the existing infrastructure (Zhang and Peeta, 2011). Infrastructure is regarded as complex engineering system as it often involves many components that, to a large extent, are open and interconnected, and include assets of different ages. As these become increasingly cyber-physical and interacting, an explicit understanding of their interdependencies for design and delivery should be necessary for the effectiveness and efficiency of the individual system and across systems.

The DSM provides a simple, compact, and visual representation of complex systems and interdependencies, which is effective in addressing decomposition and integration problems, and managing iterative tasks (e.g., design process). A DSM is a

square matrix $\left(N^{2}\right)$ with identical row and column labels, where an off-diagonal mark ('cross' in Figure 1) signifies the dependency of one element on another. Reading across a row indicates input sources, while reading down a column reveals output sinks. In Figure 1, element B provides something to or is related by element $\mathrm{E}$, and it depends on something from or relates to element A (Browning, 2001). 

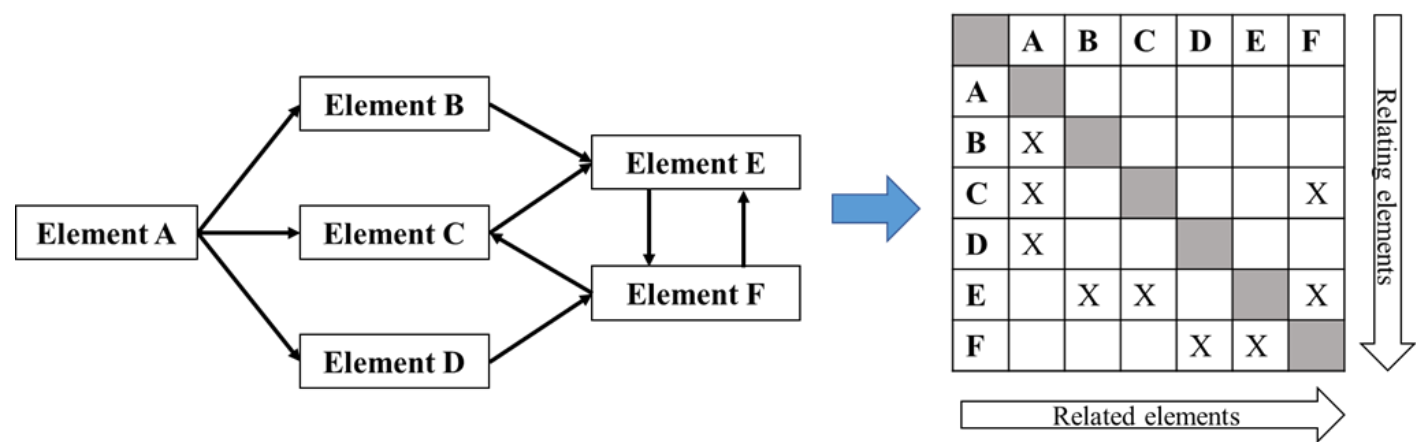

Figure 1. Related elements and the representation of interdependencies in DSM

There are four main categories of DSM in applications, including (Browning, 1999, 2001): (1) Component-based or architecture DSM, which is used for modelling system architectures based on components and/or subsystems and their relationships; (2) Team-based or organization DSM, which is used for modelling organization structures based on people and/or groups and their interactions; (3) Activity-based or schedule DSM, which is used for modelling processes and activity networks based on activities and their information flow and other dependencies; and (4) Parameter-based or low-level schedule DSM: which is used for modelling low-level relationship between design decisions and parameters, systems of equations, subroutine parameter exchanges, etc.

The use of DSM in both research and industrial practice increased greatly since the 1990s (Browning, 2001), where it has been widely applied in the construction industry for identifying and analysing interdependencies (as shown in Table 1).

However, in these researches, manual effort is often required to clarify (and/or quantify) these interdependencies in the matrix, and researchers that use the DSM often proceed by reviewing architectural diagrams, system schematics and other relevant documents, or interviewing relevant engineers and experts. It is quite labour intensive and time consuming. For example, the $46^{2}$ NASA pathfinder DSM took five months (Brady, 2002) and the $84^{2}$ Xerox printing system DSM needs three months (Suh et al., 2010). The design documents (e.g., process model and drawings) may not be available or accurate during the project delivery process (Wilschut et al., 2018). There is a need to generate DSM in a more effective and convenient way.

Table 1. System Interdependencies in Construction using DSM

\begin{tabular}{|c|c|c|c|c|}
\hline DSM Types & Authorship & $\begin{array}{l}\text { Elements of } \\
\text { DSM }\end{array}$ & $\begin{array}{l}\text { Interdependencies } \\
\text { of DSM }\end{array}$ & Data Collection \\
\hline \multirow[t]{2}{*}{ Component-based } & $\begin{array}{l}\text { Senthilkumar and } \\
\text { Varghese, } 2009\end{array}$ & Drawings & $\begin{array}{l}\text { Design issues of } \\
\text { drawings }\end{array}$ & $\begin{array}{l}\text { Interface } \\
\text { meeting }\end{array}$ \\
\hline & $\begin{array}{l}\text { Gopsill et al., } \\
2016\end{array}$ & $\begin{array}{l}\text { Digital models } \\
\text { (e.g., CAD, } \\
\left.\text { FEA }^{1}\right)\end{array}$ & $\begin{array}{l}\text { Component } \\
\text { dependencies } \\
\text { across models }\end{array}$ & $\begin{array}{l}\text { Monitoring of } \\
\text { co-occurrence } \\
\text { of model edits }\end{array}$ \\
\hline Team-based & $\begin{array}{l}\text { Senthilkumar and } \\
\text { Varghese, } 2009\end{array}$ & Design teams & $\begin{array}{l}\text { Design interfaces } \\
\text { between teams }\end{array}$ & Workshop \\
\hline \multirow[t]{2}{*}{ Activity-based } & Austin et al., 2000 & Design activities & $\begin{array}{l}\text { Design information } \\
\text { dependencies }\end{array}$ & $\begin{array}{l}\text { Design process } \\
\text { model }\end{array}$ \\
\hline & $\begin{array}{l}\text { Prasad and Jacob, } \\
2018\end{array}$ & Design activities & $\begin{array}{l}\text { Design information } \\
\text { dependencies }\end{array}$ & \\
\hline
\end{tabular}




\begin{tabular}{|c|c|c|c|c|}
\hline Parameter-based & $\begin{array}{l}\text { Pektaş and Pultar, } \\
2006 \\
\text { Pektas, } 2010 \\
\text { Jacob and } \\
\text { Varghese, } 2011 \\
\text { Jacob and } \\
\text { Varghese, } 2012 \\
\text { Saoud et al., } 2017\end{array}$ & $\begin{array}{l}\text { Design } \\
\text { parameters and } \\
\text { requirements } \\
\text { Design } \\
\text { parameters } \\
\text { Design } \\
\text { parameters } \\
\text { Design } \\
\text { parameters } \\
\text { Design } \\
\text { parameters } \\
\text { (geometry, } \\
\text { position, } \\
\text { specification) } \\
\end{array}$ & $\begin{array}{l}\text { Design information } \\
\text { flows } \\
\text { Sequence of design } \\
\text { parameters } \\
\text { Sequence of design } \\
\text { parameters } \\
\text { Spatial and } \\
\text { analytical } \\
\text { dependencies (in, } \\
\text { inter, self, join, } \\
\left.\text { host, s.host, s.sys }{ }^{2}\right) \\
\end{array}$ & $\begin{array}{l}\text { Design process } \\
\text { model } \\
\text { Design process } \\
\text { model } \\
\text { Design process } \\
\text { model } \\
\text { Interviews }\end{array}$ \\
\hline $\begin{array}{l}\text { Multi-domain } \\
\text { matrix }\end{array}$ & $\begin{array}{l}\text { Wilschut et al., } \\
2018\end{array}$ & $\begin{array}{l}\text { Components, } \\
\text { functions, and } \\
\text { parameters }\end{array}$ & $\begin{array}{l}\text { Spatial, } \\
\text { information, energy } \\
\text { and material } \\
\text { dependencies }\end{array}$ & $\begin{array}{l}\text { Structured } \\
\text { textual function } \\
\text { specifications }\end{array}$ \\
\hline
\end{tabular}

Note: ${ }^{1}$ CAD: Computer-aided design; FEA: Finite element analysis.

2 in: elements belong to; inter: intersection between; self: relation within the same item; join: elements are connected to each other; host: being the host element; s.host: two elements have the same host element; s.sys: elements are defined in one system.

\section{Digital twin and IFC standard}

Digital twins in infrastructure are defined as: "realistic digital representations of physical things. They unlock value by enabling improved insights that support better decisions, leading to better outcomes in the physical world." (Bolton, et al. 2018). Attention is drawn to the use of flows of digital information about physical assets to improve decisions, outcomes and performance. While the shift from computer-aided design to Building Information Modelling (BIM) involved the addition of asset information as well as geometry, the shift to a digital twin requires the use of a broader range of sources of data, which may involve geometries, asset information and associated time series data on processes. Such data may be generated through the activities of professionals, in production and operation, and through a range of sensing devices (including photographs, laser scans, and embedded sensors). Developing and using the rich data implied by 'digital twin' is relevant to projects to develop new infrastructure in the context of existing infrastructure systems, and to understand systems interdependencies through integration with DSM.

The IFC standard is deemed a promising open data standard for information exchange between digital twin and DSM. It is defined based on the Standard for Exchange of Product model data (STEP) (ISO 10303) and registered as ISO 167391:2018 (2018). The IFC provides a large variety of different geometry representations (e.g., Constructive Solid Geometry, Swept Area Representations and boundary representations), which can be adopted to identify spatial interdependencies. The IfcRelationship is the abstract generalization of all objectified relationships in IFC and can be adopted to handle non-spatial interdependencies among objects (buildingSMART, 2019). There are mainly six types of IfcRelationship, including IfcRelAssigns, IfcRelAssociates, IfcRelConnects, IfcRelDeclares, IfcRelDecomposes, and IfcRelDefines. 


\section{Uniclass classification system}

Uniclass is a unified classification for the UK construction industry, classifying items of all scale from a facility (e.g., airport) down through to products (e.g., a door in airport terminal building) (Delany, 2019). It provides a hierarchical suite of tables describing and classifying all 'things' to support the digital plan of work, including seven core tables (i.e., Complexes, Activities, Entities, Spaces/Location, Elements/Functions, Systems, and Products) and several additional tables (e.g., Form of Information, and Project Management). With the aid of Uniclass, information about complex engineering systems can be generated, used and retrieved throughout the life cycle.

\section{DEVELOPMENT OF DIGITAL-DSM MODEL}

This research defined the Digital-DSM, which provided a theoretical basis for generating DSM from digital model automatically. Based on extant literature, two essential building blocks of Digital-DSM were classified and identified, i.e., elements and interdependencies.

\section{Definition of Digital-DSM elements}

The elements of Digital-DSM at different scales are defined drawing on the Uniclass classification system and prior work (Pimmler and Eppinger, 1994; Senthilkumar and Varghese, 2009; Saoud et al., 2017). As shown in Table 2, there are four levels of elements defined in a top-down approach, where the definition in DigitalDSM is provided from the perspective of digital model rather than physical model in DSM.

Table 2. Definitions of Elements for Digital-DSM

\begin{tabular}{|c|c|c|c|c|}
\hline Level & $\begin{array}{l}\text { Termino } \\
\operatorname{logy}\end{array}$ & Definition in DSM & $\begin{array}{l}\text { Definition in Digital- } \\
\text { DSM }\end{array}$ & Example \\
\hline $\begin{array}{l}\text { System } \\
\text {-of- } \\
\text { systems }\end{array}$ & $\begin{array}{l}\text { Complex } \\
\text { es }\end{array}$ & $\begin{array}{l}\text { Assembly of physical } \\
\text { systems for high- } \\
\text { level functions }\end{array}$ & $\begin{array}{l}\text { Main file defined as } \\
\text { assembly of systems for } \\
\text { high-level functions }\end{array}$ & $\begin{array}{l}\text { - } \\
\text { - }\end{array}$ \\
\hline Project & Project & $\begin{array}{l}\text { Geographically } \\
\text { distinct entity created } \\
\text { to meet specific high- } \\
\text { level functions for the } \\
\text { users of the project. }\end{array}$ & $\begin{array}{l}\text { Sub file defined as } \\
\text { digital model created for } \\
\text { geographical distinct } \\
\text { entity. }\end{array}$ & $\begin{array}{l}\text { - } \quad \text { Terminal building project; } \\
\text { - } \quad \text { Railway station project. }\end{array}$ \\
\hline \multirow[t]{2}{*}{ Asset } & $\begin{array}{l}\text { Sub- } \\
\text { system }\end{array}$ & $\begin{array}{l}\text { Physical entity } \\
\text { created to meet } \\
\text { specific functions for } \\
\text { the project }\end{array}$ & $\begin{array}{l}\text { System defined as digital } \\
\text { model created for } \\
\text { physical entity with } \\
\text { specific functions in each } \\
\text { sub file. }\end{array}$ & $\begin{array}{l}\text { Architecture, structure, } \\
\text { MEP, HVAC system etc. } \\
\text { for terminal building; } \\
\text { Architecture, structure, } \\
\text { MEP system etc. for } \\
\text { railway station; }\end{array}$ \\
\hline & $\begin{array}{l}\text { Compon } \\
\text { ent }\end{array}$ & $\begin{array}{l}\text { Physical entity with } \\
\text { specific functions in } \\
\text { each sub-system. }\end{array}$ & $\begin{array}{l}\text { Family of objects with a } \\
\text { common set of } \\
\text { properties, called } \\
\text { parameters, and a related } \\
\text { graphical representation } \\
\text { in each sub-system. }\end{array}$ & $\begin{array}{l}\text { - Duct, beam, column etc. } \\
\text { in building. }\end{array}$ \\
\hline
\end{tabular}




\begin{tabular}{lllll} 
& $\begin{array}{l}\text { Digital } \\
\text { compone } \\
\mathrm{nt}\end{array}$ & - & $\begin{array}{l}\text { Specific digital object } \\
\text { with unique ID in each } \\
\text { family. }\end{array}$ & $\begin{array}{l}\text { \#1 duct, \#2 duct, \#1 beam } \\
\text { etc. in building }\end{array}$ \\
$\begin{array}{l}\text { Parame } \\
\text { ter }\end{array}$ & $\begin{array}{l}\text { Paramete } \\
\mathrm{r}\end{array}$ & $\begin{array}{l}\text { Input/Output data } \\
\text { to/of the design } \\
\text { process }\end{array}$ & $\begin{array}{l}\text { Design parameters as the } \\
\text { properties of objects. }\end{array}$ & $\begin{array}{l}\text { Depth of footing, cut-out } \\
\text { sizes; }\end{array}$ \\
& & & $\begin{array}{l}\text { Cut-out sizes and duct } \\
\text { elevation, etc. }\end{array}$ \\
\hline
\end{tabular}

\section{Definition of Digital-DSM interdependencies}

Based on literature review, the interdependencies in Digital-DSM are defined in three types, including the geospatial (Borrmann and Rank, 2009), physical (Borrmann et al., 2015; buildingSMART, 2019) and logical (buildingSMART, 2019).

The geospatial interdependencies were defined according to the 9-intersection model in 3D space (Borrmann and Rank, 2009) for spatial analyses, while the physical and logical interdependencies were defined based on the IfcRelationship for nonspatial analyses. Although these interdependencies are defined across scales, this paper will only focus on the asset level interdependencies to provide an example for the generation of Digital-DSM (Table 3).

Table 3. Definitions of Elements for Digital-DSM at Asset Level

\begin{tabular}{|c|c|c|c|}
\hline Types & Terminology & Details & Definition \\
\hline $\begin{array}{l}\text { Geospat } \\
\text { ial }\end{array}$ & $\begin{array}{l}\text { Physical } \\
\text { adjacency }\end{array}$ & $\begin{array}{l}\text { Disjoint; } \\
\text { Contain; Within; } \\
\text { Touch; Overlap }\end{array}$ & $\begin{array}{l}\text { The physical adjacency or topological } \\
\text { relationship between each asset. }\end{array}$ \\
\hline Physical & $\begin{array}{l}\text { Material } \\
\text { specification }\end{array}$ & $\begin{array}{l}\text { IfcRelAssociates } \\
\text { Material }\end{array}$ & $\begin{array}{l}\text { An objectified relationship between a } \\
\text { material definition and elements or } \\
\text { element types to which this material } \\
\text { definition applies } 3\end{array}$ \\
\hline \multirow[t]{2}{*}{ Logical } & Group & $\begin{array}{l}\text { IfcRelAssignsTo } \\
\text { Group }\end{array}$ & $\begin{array}{l}\text { An objectified relationship assigning } \\
\text { object definitions (IfcObject or } \\
\text { IfcTypeObject) to a group (IfcGroup) }\end{array}$ \\
\hline & Resource share & $\begin{array}{l}\text { IfcRelAssignsTo } \\
\text { Resource }\end{array}$ & $\begin{array}{l}\text { An objectified relationship assigning } \\
\text { objects (IfcObject), acting as a } \\
\text { resource usage or consumption, to a } \\
\text { resource (IfcResource) }\end{array}$ \\
\hline
\end{tabular}

\section{Strategy to generate asset level Digital-DSM}

According to the elements and interdependencies defined, an Open BIM approach is proposed based on IFC and BIM query methods to generate the DigitalDSM. This research used the Thames Tideway Tunnel in London as a case study to demonstrate how this approach can be applied in analysing system interdependencies in practice. With the help of BIM Views and Query engine in BIMserver, the IFC file of Tideway can be read, visualized (as Figure 2(a)(b)), and decomposed into different layers of components at asset level (as Figure 2(c)(d)).

Among these components, five kinds of them were selected randomly as the elements for constructing DSM, and the interdependencies between such components were identified according to the definition in Table 3 using Query engine. Two kinds of DSMs were thus generated to show the geospatial and physical interdependencies 
between components. Using the DSMs, the design teams will be able to clearly understand the impact of design change. For example, if component B ' $C$-L151$M \_$Sheet piles' is changed, then element E 'C-G215-M_Foundations Piles' will be affected in both spatial location and material.

The results clearly clarify the complexity of the complex engineering systems, Tideway, and are helpful to understand the design change propagation and impacts.

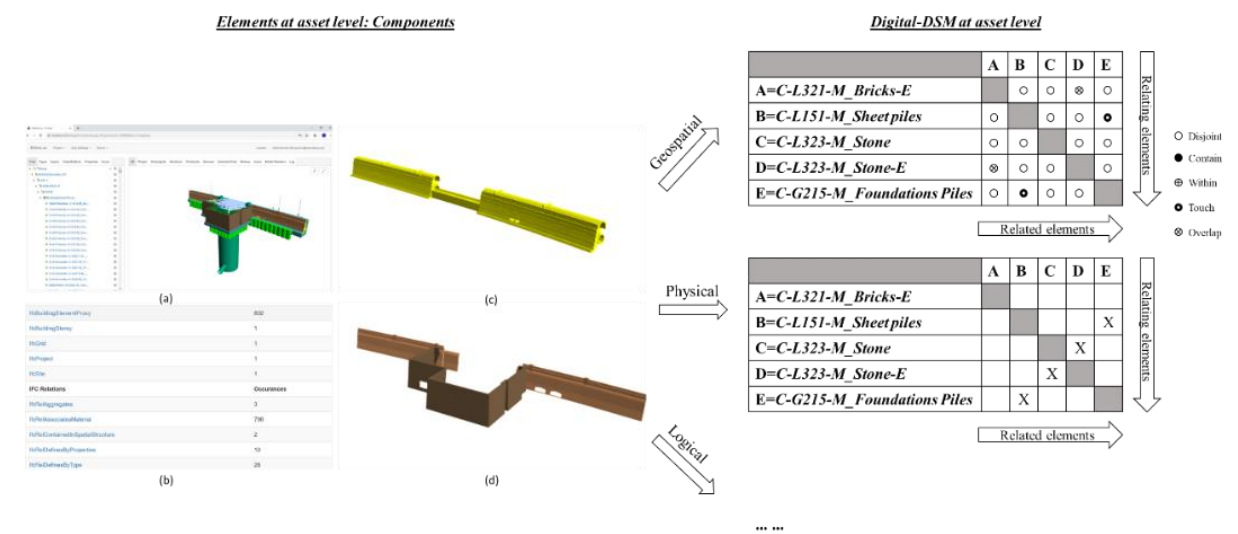

Figure 2. Generating Digital-DSM for Tideway at asset level

\section{DISCUSSION AND CONCLUSIONS}

Late design change can introduce uncertainty and complexity into the design of complex systems, where identifying interdependencies is significant to ensure the accuracy and consistency of data. Compared to the conventional design change process, the digital twin-driven DSM for design change can perform better in processing time, cost, and accuracy (Table 4). There is no need for designers to track design changes and propagation manually. The proposed approach can help to automatically construct the DSM according to identified interdependencies at asset-level and manage the change propagation through following these interdependencies.

This research has taken steps towards developing a novel and effective way to simplify complexity and clarify interdependencies in complex systems through generating DSM from a digital twin (e.g., BIM). To do so, the Digital-DSM has been defined in terms of elements and interdependencies across scales, providing a theoretical understanding for integrating digital twin with DSM in analysing systems interdependencies. A prototype based on Tideway has been provided to illustrate how the Digital-DSM helps to improve the efficiency of late design change in complex engineering systems. The results show that the Digital-DSM can make a practical contribution to the identification, analyses and management of interdependencies, and is promising to improve the design efficiency of complex engineering systems.

Future work will focus on (1) validating and tailoring the proposed approach through more case studies and feedbacks from the industry; (2) the extension of DigitalDSM theoretical model to address the limited kinds of interdependencies defined in Digital-DSM; and (3) integrating the Digital-DSM with design change propagation algorithms to evaluate the impact of design change quantitively. 
Table 4. Comparison between Conventional and Proposed Design Change Process in Analysing Interdependencies

\begin{tabular}{|c|c|c|}
\hline $\begin{array}{l}\text { Evaluation } \\
\text { Metrics }\end{array}$ & $\begin{array}{l}\text { Conventional Design } \\
\text { Change Process }\end{array}$ & Digital Twin-Driven DSM \\
\hline Processing time & $\begin{array}{l}\text { Time-consuming with } \\
\text { manual efforts }\end{array}$ & $\begin{array}{l}\text { High efficiency with automatic } \\
\text { identification and analyses }\end{array}$ \\
\hline Cost & High labour cost & $\begin{array}{l}\text { Low labour cost with digital twin } \\
\text { supported }\end{array}$ \\
\hline Accuracy & $\begin{array}{l}\text { Highly depended on } \\
\text { expertise }\end{array}$ & $\begin{array}{l}\text { Based on definition of } \\
\text { interdependencies }\end{array}$ \\
\hline $\begin{array}{l}\text { Level of design } \\
\text { change }\end{array}$ & $\begin{array}{l}\text { Asset, project and system- } \\
\text { of-systems levels }\end{array}$ & $\begin{array}{l}\text { Asset-level, but can be expanded to } \\
\text { others }\end{array}$ \\
\hline
\end{tabular}

\section{REFERENCES}

Austin, S., Baldwin, A., Li, B., and Waskett, P. (2000). "Application of the analytical design planning technique to construction project management". Project Management Journal, 31(2), 48-59.

Bolton, A., Butler, L., Dabson, I., Enzer, M., Evans, M., Fenemore, T., Harradence, F., et al. (2018). Gemini Principles. (CDBB_REP_006)

Borrmann, A., König, M., Koch, C., and Beetz, J. (2015). Building Information Modeling: Technology Foundations and Industry Practice. Springer, Cham.

Borrmann, A., and Rank, E. (2009). "Topological analysis of 3D building models using a spatial query language". Advanced Engineering Informatics, 23(4), 370-385.

Brady, T. K. (2002). "Utilization of dependency structure matrix analysis to assess complex project designs". In: ASME 2002 international design engineering technical conferences and computers and information in engineering conference. American Society of Mechanical Engineers, 231-240

Browning, T. R. (2001). "Applying the design structure matrix to system decomposition and integration problems: a review and new directions". IEEE Transactions on Engineering management, 48(3), 292-306.

buildingSMART. (2019). "Industry Foundation Classes Version 4.2" <https://standards.buildingsmart.org/IFC/DEV/IFC4_2/FINAL/HTML/> (Jul. $16,2019)$

Davies, A. (2017). Projects: A Very Short Introduction, Oxford University Press.

Delany, S. (2019). "UNICLASS Classification" $<$ https://toolkit.thenbs.com/articles/classification> (Jul. 16, 2019)

Eusgeld, I., Nan, C., and Dietz, S. (2011). "“'System-of-systems” approach for interdependent critical infrastructures". Reliability Engineering \& System Safety, 96(6), 679-686.

Goldbeck, N., Angeloudis, P., and Ochieng, W. Y. (2019). "Resilience assessment for interdependent urban infrastructure systems using dynamic network flow models". Reliability Engineering \& System Safety, 188, 62-79.

Gopsill, J. A., Snider, C., McMahon, C., and Hicks, B. (2016). "Automatic generation of design structure matrices through the evolution of product models". AI EDAM, 30(4), 424-445.

ISO 16739-1:2018 (2018). Industry Foundation Classes (IFC) for Data Sharing in the Construction and Facility Management Industries. 
Jacob, J., and Varghese, K. (2011). "Integration of BIM and DSM to improve design process in building construction projects". In $13^{\text {th }}$ International Dependency and Structure Modelling Conference, 14-15 September, Cambridge, MASSACHUSETTS, USA.

Jacob, J., and Varghese, K. (2012). "A model for product-process integration in the building industry using industry foundation classes and design structure matrix". In Construction Research Congress 2012: Construction Challenges in a Flat World, 21-23 May, West Lafayette, Indiana, USA.

Lambe, A. B., and Martins, J. R. (2012). "Extensions to the design structure matrix for the description of multidisciplinary design, analysis, and optimization processes". Structural and Multidisciplinary Optimization, 46(2), 273-284.

Pektas, S. T. (2010). "The complementary use of the parameter-based design structure matrix and the IFC process models for integration in the construction industry". In The 12th International DSM Conference, 22-23 July, Cambridge, UK.

Pektaş, Ş. T., and Pultar, M. (2006). "Modelling detailed information flows in building design with the parameter-based design structure matrix". Design Studies, 27(1), 99-122.

Pimmler, T. U., and Eppinger, S. D. (1994). "Integration analysis of product decompositions". In ASME Design Theory and Methodology Conference, September, Minneapolis, MN, USA.

Prasad, A., and Jacob, J. (2018). "A Framework for Incorporating Dependency Structure Matrix in Building Design Process". International Research Journal of Engineering and Technology, 5(4), 4938-4945.

Saoud, L. A., Omran, J., Hassan, B., Vilutienè, T., and Kiaulakis, A. (2017). “A method to predict change propagation within building information model". Journal of Civil Engineering and Management, 23(6), 836-846.

Senthilkumar, V., and Varghese, K. (2009). "Structured methodology to formulate drawing dependency structure matrix for construction design". Architectural Engineering and Design Management, 5(4), 225-248.

Suh, E. S., Furst, M. R., Mihalyov, K. J., and Weck, O. D. (2010). "Technology infusion for complex systems: A framework and case study". Systems Engineering, 13(2), 186-203.

Whyte, J. (2019). "How Digital Information Transforms Project Delivery Models". Project Management Journal, 50(2), 177-194.

Whyte, J., Stasis, A., and Lindkvist, C. (2016). "Managing change in the delivery of complex projects: Configuration management, asset information and 'big data". International Journal of Project Management, 34(2), 339-351.

Wilschut, T., Etman, L. F. P., Rooda, J. E., and Vogel, J. A. (2018). "Generation of a function-component-parameter multi-domain matrix from structured textual function specifications". Research in Engineering Design, 29(4), 531-546.

Zhang, P., and Peeta, S. (2011). "A generalized modeling framework to analyze interdependencies among infrastructure systems". Transportation Research Part B: Methodological, 45(3), 553-579. 